\begin{abstract}
Fine-scale movements of and use of habitat space by individual marine fishes can structure broader population dynamics, yet little is known about these traits. This lack of key information applies to the economically and ecologically important sciaenid weakfish ( $C y$ noscion regalis), which is seasonally distributed in estuaries and coastal habitats along the Middle Atlantic Bight, where it feeds and spawns. We examined movements of adult weakfish in a southern New Jersey estuary using acoustic telemetry at both seasonal ( $n=29$ fish) and diel ( $n=9$ fish) scales. From June through November 2008, a majority of tagged and redetected weakfish (12 of 20; $60 \%$ ) established areas of localized residency. Several fish made excursions of varying distances (1.0-5.9 $\mathrm{km}$ ) from these regions before returning after 1-2 weeks. At the diel scale, most weakfish ( 7 of $9 ; 78 \%$ ) resided as a local aggregation during the day and made nighttime excursions beginning around sundown (1930 hours). No fish were detected within $0.5 \mathrm{~km}$ of their area of localized daytime residency after 2230 hours. These findings are new evidence of the affinity of adult weakfish within specific localities across ecologically relevant timescales and offer further insight into the importance of estuaries in the life history of weakfish.
\end{abstract}

Manuscript submitted 19 September 2013. Manuscript accepted 5 February 2015. Fish. Bull. 113:167-179 (2015). doi: $10.7755 /$ FB.113.2.5

The views and opinions expressed or implied in this article are those of the author (or authors) and do not necessarily reflect the position of the National Marine Fisheries Service, NOAA.

\title{
Patterns of intra-estuarine movement of adult weakfish (Cynoscion regalis): evidence of site affinity at seasonal and diel scales
}

\author{
Jason T. Turnure \\ Kenneth W. Able (contact author) \\ Thomas M. Grothues \\ Email address for contact author: able@marine.rutgers.edu \\ Marine Field Station \\ Institute of Marine and Coastal Sciences \\ Rutgers, the State University of New Jersey \\ 800 c/o 132 Great Bay Boulevard \\ Tuckerton, New Jersey 08087-2004
}

Population connectivity in fishes is directed by the movements and space-use patterns of individuals in populations. We must first understand these individual behaviors to fully understand the role of population connectivity and how it informs tools used to maintain sustainable fisheries (Mittelbach et al., 2014). Fine-scale movements and related patterns of site affinity and homing have been examined extensively in terrestrial (Bright and Morris, 1991; Costello, 2010) and avian (Hoppes, 1987) species, and improvements in our ability to track marine animals with greater resolution, in both time and space, have shed light on similar behaviors (March et al., 2010). Studies of fine-scale movements of fishes have elucidated their ability to home back to relatively small geographic areas (Mitamura et al., 2009), keep restricted home ranges (McGrath and Austin, 2009), and maintain site affinity at timescales that range from daily (Humston et al., 2005) to yearly (Ng et al., 2007). Effects of scale, although important for examining ecological processes, are neglected too frequently during evaluation of animal movements (Levin, 1992; Schick et al., 2008). Therefore, obtaining ap- propriately scaled data on the movements of exploited marine fishes is an increasingly warranted goal (Pittman and McAlpine, 2003).

Estuarine movements of adult weakfish (Cynoscion regalis) are poorly understood despite their relative importance within the estuarine food web, their economic contribution to both recreational and commercial fisheries (Able and Fahay, 1998), and most recent coast-wide population decline $\left(\mathrm{NEFSC}^{1}\right)$. Weakfish range from the Gulf of Maine during some years (Collette and Klein-MacPhee, 2002) to the southwest Atlantic coast where they maintain year-round residency. They are seasonal residents in the northern portion of their range within the Middle Atlantic Bight between New York and Virginia, where migrations move south and offshore in the fall and north and inshore in the spring (Shepherd and Grimes,

1 NEFSC (Northeast Fisheries Science Center). 2009. Weakfish assessment summary for 2009. In 48th Northeast Regional Stock Assessment Workshop (48th SAW) assessment summary report, Northeast Fish. Sci. Cent. Ref. Doc. 09-10, p. 41-46, [Available from http:// www.nefsc.noaa.gov/publications/crd/ crd0910/crd0910.pdf.] 


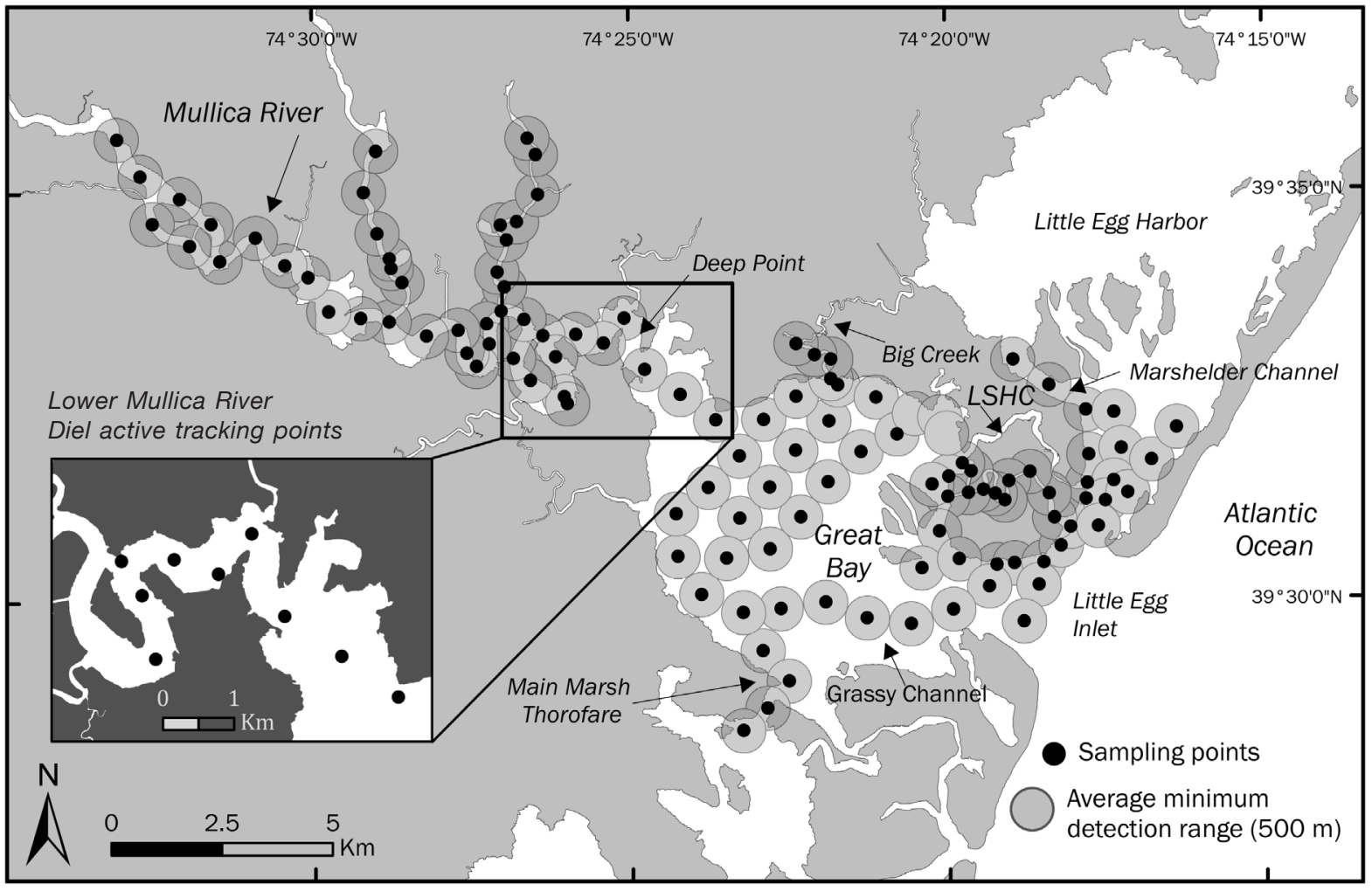

Figure 1

Study areas within the Mullica River-Great Bay estuary in southern New Jersey for the seasonal and diel scales in the study of weakfish (Cynoscion regalis) movement conducted in 2008. The locations of the sampling points (120) were monitored with active telemetry used to evaluate seasonal movements in 2008, including the area (shown in the inset square box) at Deep Point in the lower Mullica River surveyed for an the evaluation of diel movements. LSHC=Little Sheepshead Creek.

1984). Although weakfish occur in estuaries and innercontinental-shelf habitats, the relative importance of estuarine systems within these regions is mostly unknown (Able, 2005; Woodland et al., 2012). We do know that they establish seasonal residency in estuaries in the Middle Atlantic Bight (Turnure et al., in press; Manderson et al., 2014), where they both feed (Harfmart and Brandt, 1995) and reproduce (May-July; Connaughton and Taylor, 1994, 1995; Luczcovich et al., 1999; Able and Fahay, 2010). Previous egg and plankton sampling (Ferraro, 1980), reproductive histology (Lowerre-Barbieri et al., 1996; Nye et al., 2008), and gonadosomatic indices (Taylor and Villoso, 1994) have delineated weakfish as iteroparous nocturnal spawners, generally commencing reproductive behavior around the evening crepuscular period. In both field and laboratory passive acoustic studies, the drumming of the swim bladder of weakfish before spawning has been used to better define their location (Luczkovich et al., 1999) and the diel periodicity (Connaughton and Taylor, 1995) of their reproduction.

Because aspects of weakfish life history (e.g., reproduction and migration) occur at multiple temporal scales (i.e., seasonally and daily), it is prudent to evaluate weakfish estuarine movements within these time frames. Earlier investigations of weakfish movements within estuaries had been either too geographically coarse to resolve fine-scale patterns at biologically relevant timescales for individuals (Nesbit, 1954; Thorrold et al., 2001) or were limited to juveniles (Tyler and Targett, 2007). Previous research also has quantified homing to natal estuarine systems, suggesting that weakfish exhibit a high degree of spawning-site fidelity over broad regional areas (i.e., Chesapeake Bay and Delaware Bay; Thorrold et al., 2001), but the degree to which weakfish use small, shallow estuaries is relatively unknown, with the exception of a recent study (Manderson et al., 2014). A better understanding of weakfish movements and how extensively and intensively individuals use these estuarine habitats will clarify aspects of their complex life history and population dynamics (i.e., connectivity between estuaries and coastal habitats) and begin to delineate critical habitats for this species.

Our objectives were to characterize and quantify the fine-scale patterns of movement of individual adult weakfish at seasonal and diel temporal scales within a relatively undisturbed estuarine system (Mullica 
River-Great Bay estuary, New Jersey). At the seasonal scale, active (i.e., mobile) telemetry was used to quantify estuary-wide, meter-scale movements of individually tagged animals on a weekly basis across the months from late spring to fall. At the diel scale, patterns of movement and distribution were examined on an hourly basis through the use of active telemetry during the summer months.

\section{Materials and methods}

\section{Study areas}

Seasonal movements were examined in the Mullica River-Great Bay estuary and adjacent Little Egg Harbor estuary, and diel movements were examined in a small region in the lower Mullica River known as Deep Point (Fig. 1). The Mullica River-Great Bay system is a relatively small, shallow (with depths mostly $<2 \mathrm{~m}$ ), drowned river valley dominated by salt marsh (Kennish, 2004). With the majority of its upstream portion flowing through the undeveloped Pinelands National Reserve, this watershed is considered one of the least anthropogenically disturbed estuaries in the northeastern United States (Good and Good, 1984; Kennish and O'Donnell, 2002). The adjacent Little Egg Harbor estuary is also relatively shallow, but it is characterized as a barrier island estuary with significantly fewer freshwater inputs than the Mullica River-Great Bay system (Kennish, 2001, 2004). Both estuaries are included within the NOAA Jacques Cousteau National Estuarine Research Reserve (Kennish, 2004).

\section{Acoustic telemetry}

Tagging procedure and general characteristics of tagged fish All adult weakfish ( $>230 \mathrm{~mm}$ in total length [TL], which is size at maturity based on Nye et al., 2008) examined in this study were captured by hook and line and subsequently tagged during 2008 (from 11 June to 11 September) by abdominal implantation of individually coded acoustic transmitters (CAFT and MS series ${ }^{2}$, Lotek Wireless Inc., St. John's, Newfoundland; with a 5-s signal repeat rate) by the method of Turnure et al. (in press). After full recovery, fish were released within $100 \mathrm{~m}$ of their original site of capture (Table 1).

Seasonal patterns of movement were observed in 2008 for acoustically tagged fish $(n=29$; length range: 273-591 mm TL, mean: $401 \mathrm{~mm}$ [standard error (SE) 15) from 19 May to 4 December 2008. A subset of individuals ( $\mathrm{n}=9$; length range: $337-540 \mathrm{~mm}$ TL, mean: $456 \mathrm{~mm}$ TL [SE 22]) were monitored at the diel scale in the lower Mullica River at Deep Point (Fig. 1) from 30 June to 31 July 2008. Active tracking, as part of a con-

\footnotetext{
2 Mention of trade names or commercial companies is for identification purposes only and does not imply endorsement by the National Marine Fisheries Service, NOAA
}

current study (Turnure et al., in press), began in May 2008 to detect weakfish (tagged in 2007) that were potentially immigrating to the estuary. However, no such immigrants were detected in 2008. All fish monitored in the study presented herein were tagged beginning in June 2008. The area used in the study of diel movements was chosen because multiple fish were tagged and released there, making it possible to examine their day-night movements as an aggregation. All fish used in these analyses were considered successfully tagged on the basis of subsequent redetections or movement from the study area (Turnure et al., in press). The battery duration of the deployed acoustic transmitters ranged from 229 to 719 days for both the seasonal and diel components of this study, allowing for monitoring of fish until final emigration from the study area in the fall (for further description of weakfish emigration, see Turnure et al., in press).

Active telemetry Active telemetry was used at both the seasonal and diel scales to examine patterns of movement in 2008. For active tracking from a small boat, a directional hydrophone (LHP_1, Lotek Wireless Inc., Newmarket, Ontario, Canada) was attached to a signal processor (SRX-400, Lotek Wireless Inc.). At each predetermined sampling location (Fig. 1), the hydrophone was lowered approximately $3 \mathrm{~m}$ underwater and turned in $90^{\circ}$ increments for a full rotation. When transmitters were audibly detected, the boat was positioned to maintain close proximity (signal power $>115 \mathrm{~dB}$ and gain $<15$ ) and fish location was recorded, with a GPS unit, together with the tag identification number, signal power (in decibels), and gain. Although variable because of ambient weather conditions, the active listening range of the hydrophone averaged approximately $500 \mathrm{~m}$. For further discussion of the general active tracking procedure in this estuary, see $\mathrm{Ng}$ et al. (2007), Sackett et al. (2007), and Turnure et al. (in press).

Every week from 19 May to 4 December 2008 (except for the week of 17 November because of inclement weather), 120 predetermined locations (Fig. 1) that covered a majority of the navigable Mullica RiverGreat Bay system were sampled during daylight hours (0700-1900) as described previously. For most of the tracking events, both the bay and river locations were sampled on different days within the same week (for a detailed description of tracking protocol, see Turnure et al., in press).

Active tracking also occurred from 30 June to 31 July 2008 (9 tracking events), to identify diel patterns of movement in weakfish near Deep Point in the Mullica River. During each tracking event, the sampling locations in a subset of 9 predetermined points were visited on a rotating basis (Fig. 1). After detection and subsequent meter-scale localization of individuals at a tracking point, the subsequent locations were visited until work at all 9 points was completed. Then, the rotation was repeated, beginning at point 1 until the daily tracking event was over. The average tracking event lasted $5 \mathrm{~h}$ and $43 \mathrm{~min}$. To determine the effect 


\section{Table 1}

Tagging characteristics and patterns of intra-estuarine residency for individually tagged weakfish (Cynoscion regalis) within the Mullica River-Great Bay estuary in 2008 (20 of 29 fish successfully tagged). Areas of localized residency (ALR) were established by 12 of 29 individuals (ALR defined as 3 or more consecutive weekly detections within $500 \mathrm{~m}$ of each other). No data (-) indicates fish without sufficient redetections $(<3)$ to analyze patterns of movement $(1$ of 29 total fish tagged) or that did not establish an ALR, on the basis of previously described criteria (8 of 29 total fish tagged). Potential relocation events are calculated as the number of weekly tracking events in which fish were resident in the study area. An asterisk (*) indicates established ALR is the same as original tagging location. LSHCW=western side of Little Sheepshead Creek; LSHCE=eastern side of Little Sheepshead Creek; SWGB=southwestern Great Bay (for locations, see Fig. 1); NEGB=northeastern Great Bay; MMT=Main Marsh Thorofare.

\begin{tabular}{|c|c|c|c|c|c|c|c|c|c|c|}
\hline $\begin{array}{c}\text { Fish } \\
\text { ID }\end{array}$ & $\begin{array}{l}\text { Length } \\
\text { (mm TL) }\end{array}$ & $\begin{array}{c}\text { Date } \\
\text { tagged }\end{array}$ & $\begin{array}{l}\text { Tagging } \\
\text { location }\end{array}$ & $\begin{array}{c}\text { Total } \\
\text { number of } \\
\text { detections }\end{array}$ & $\begin{array}{c}\text { Area of } \\
\text { localized } \\
\text { residency }\end{array}$ & $\begin{array}{c}\text { First } \\
\text { detection } \\
\text { within } \\
\text { ALR }\end{array}$ & $\begin{array}{c}\text { Last } \\
\text { detection } \\
\text { within } \\
\text { ALR }\end{array}$ & $\begin{array}{c}\text { Size of } \\
\text { ARL } \\
\left(\mathrm{km}^{2}\right)\end{array}$ & $\begin{array}{c}\text { No. of } \\
\text { detections } \\
\text { in ALR }\end{array}$ & $\begin{array}{l}\text { Proportion } \\
\text { of potential } \\
\text { detections } \\
\text { within } \\
\text { ALR }(\%)\end{array}$ \\
\hline 38 & 298 & Aug 22 & LSHCW & 1 & - & - & - & - & - & - \\
\hline 62 & 406 & Jul 1 & Deep Point & 7 & - & - & - & - & - & - \\
\hline 64 & 337 & Jul 10 & Deep Point & 8 & $*$ & July 17 & Oct 16 & 0.123 & 6 & 35 \\
\hline 70 & 406 & Jul 10 & Deep Point & 3 & - & - & - & - & - & - \\
\hline 74 & 356 & Aug 17 & Grassy Channel & 3 & - & - & - & - & - & - \\
\hline 75 & 279 & Aug 15 & LSHCW & 6 & $*$ & Aug 22 & Sep 23 & 0.004 & 5 & 56 \\
\hline 102 & 591 & Jul 1 & Deep Point & 11 & SWGB & Aug 22 & Oct 15 & 0.104 & 6 & 35 \\
\hline 103 & 521 & Jun 21 & Deep Point & 3 & - & - & - & - & - & - \\
\hline 137 & 489 & Jul 1 & Deep Point & 13 & $*$ & Jul 2 & Jul 23 & 0.028 & 4 & 24 \\
\hline 138 & 432 & Aug 12 & LSHCW & 8 & NEGB & Sep 3 & Oct 8 & 0.009 & 4 & 40 \\
\hline 139 & 470 & Aug 15 & Big Creek & 10 & $*$ & Aug 27 & Oct 15 & 0.007 & 5 & 50 \\
\hline 140 & 432 & Aug 17 & Grassy Channel & 4 & MMT & Aug 27 & Sep 18 & 0.034 & 4 & 80 \\
\hline 142 & 445 & Aug 27 & LSHCE & 4 & $*$ & Sep 12 & Sep 23 & 0.001 & 3 & 75 \\
\hline 151 & 502 & Jun 21 & Deep Point & 7 & * & Jul 2 & Aug 5 & 0.036 & 6 & 46 \\
\hline 155 & 432 & Jun 12 & Big Creek & 4 & $*$ & Jun 17 & Jul 16 & 0.003 & 4 & 67 \\
\hline 162 & 438 & Jun 19 & Deep Point & 7 & - & - & - & - & - & - \\
\hline 163 & 406 & Sep 11 & Marshelder & 4 & - & - & - & - & - & - \\
\hline 204 & 457 & Jun 25 & Deep Point & 1 & - & - & - & - & - & - \\
\hline
\end{tabular}

of the crepuscular and nighttime periods on weakfish movements, tracking occurred during and after sundown (1930 hours, 5 tracking events).

\section{Data analysis}

Seasonal movements The sampling unit $(n)$ was defined as an individual tagged fish (Rogers and White, 2007) to avoid pseudoreplication. Redetections of individual weakfish during seasonal active tracking in 2008 were first plotted with geographic information systems (GIS) software (ArcMap 9.3, Esri, Redlands, CA). Quantifying the breadth of movements in animals has traditionally been accomplished by calculating home ranges, but the lack of consecutive detections in tagged weakfish during this study precluded formal home range analyses (Rogers and White, 2007). Kernel density estimators, another technique used for home range calculation in previous studies (e.g., McGrath and Austin, 2009), would have produced bias in estimates because of low sample size (Seaman et al., 1999) and nonconsecutive detections. Variations of these analyses were conducted but proved inadequate. For example, movement rates could not be assessed on a daily scale (kilometers per day) because sampling occurred weekly and weekly rates of movement were largely uninformative at such a large timescale and were confounded by weeks during which fish were not redetected. Movements were analyzed in relation to environmental factors, such as salinity and temperatures, but these findings were also misleading because environmental conditions in an estuarine system are highly dynamic (changing with each tidal cycle).

To characterize seasonal weakfish movements, criteria based on the spatial and temporal extent of weekly redetections were established. If 3 consecutive detections of tagged weakfish were within $500 \mathrm{~m}$ of each other, the fish were characterized as having established an area of localized residency (ALR; see Table 1). Only fish with 3 or more weekly detections were used in analy- 
sis of estuarine movement patterns, and all detections within an ALR before or after this 3-week period were included in analysis. Patterns of weakfish movement remained consistent even at lower temporal thresholds (i.e., 2 consecutive detections within $500 \mathrm{~m}$ ), indicating the robustness of the ALR metric for these data.

Calculation of the size of an ALR was made with the minimum convex polygon metric whereby the inner points of detection were completely enclosed by a minimum number of outer detection points that form a convex polygon. Weekly movements were calculated as minimum straight-line distances (in kilometers) from an ALR. If the original release site fell within this area, the release location was used to calculate subsequent movement distances. Otherwise, a geometric centroid of detections within the ALR was used. The total area sampled during active tracking was determined by areal analysis of active tracking points and their ranges of detection (see Fig. 1), and by excluding areas where the detection ranges fell on land. ALR differs from home range, a strictly spatial descriptor of animal activity, in that ALR incorporates a temporal component (i.e., 3 consecutive weekly detections in our study) and an explicit spatial component (detections within $500 \mathrm{~m}$ of one another) to describe weakfish site affinity.

Diel movements Redetections of individual weakfish during diel active tracking in 2008 were first plotted with ArcMap 9.3 GIS software. To characterize weakfish movements at the diel scale, we measured the minimum straight-line distance (in kilometers) across water of individual weakfish from an area of localized daytime residency (ALDR) at Deep Point in the Mullica River (Fig. 1). The location of the ALDR was determined by the previously defined seasonal ALR for individuals tagged in this region (see Table 1), with the exception of a single fish (ID 100) that did not establish an ALR. Distances of fish from their ALDR were binned into 2 -h increments to observe diel movement patterns. Nighttime was defined as the period from 1 $\mathrm{h}$ before sundown to $1 \mathrm{~h}$ before sunrise (1930-0429 hours) to account for potential behavioral changes (e.g., reproduction) related to the dusk and dawn periods that have been identified previously in weakfish (Connaughton and Taylor, 1995). Daytime was defined as the period from 0430 to 1929 hours. We compared the average distance of individuals from their ALDR during daytime and nighttime detections using the nonparametric Mann-Whitney $U$-test (2-tailed, $\alpha=0.05$ ).

\section{Results}

\section{Seasonal patterns of movement}

Overall patterns of estuarine movements were variable among individual weakfish. A majority of redetected weakfish (12 of $20 ; 60 \%$ ) established an ALR within the study area, and some redetected fish (6 of 20;30\%) with sufficient redetections for analysis did not dis- play this localized pattern (Table 1). Of the remaining tagged fish, 9 fish were never redetected during active tracking and 2 fish were not sufficiently redetected $(<3$ detections) for analysis of estuarine movements. Of those fish that established an ALR, the degree of use differed between individuals. Many of the latter fish, however, were detected for a majority of the time within their ALR (mean: 51\% [SE 5]; Table 1).

Weakfish established an ALR in different locations and habitats within the estuary. In general, 4 representative patterns of ALRs were observed (for examples, see Fig. 2). These ALRs were established within subtidal creeks and thoroughfares (Fig 2A; 6 of 12 locations), as well as within bay (Fig 2B; 2 of 12 locations) and river (Fig 2C; 4 of 12 locations) habitats to varying degrees, and there was an association observed between original release site and location of an ALR (9 of 12 fish; Table 1). The average size of an ALR $\left(0.03 \mathrm{~km}^{2}\right.$ [SE 0.01]), based on minimum convex polygon calculations, encompassed a small proportion $(0.06 \%)$ of the total area sampled during active tracking $\left(48.4 \mathrm{~km}^{2}\right)$. Other tagged fish (6 of 29) that did not fit the criteria for establishment of an ALR were located within similarly localized portions of the estuary (Fig. 2D). Several individuals (IDs 62, 70, 103, and 162) were redetected for 2 consecutive weeks at locations within a range of $0.10-1.08 \mathrm{~km}$ from their previous locations.

The magnitude and duration of movements of fish from an established ALR differed. Several tagged fish (5 of 12) were observed at their ALR for 4-7 sampling weeks, and their final detections were at distances of $0.9-11.9 \mathrm{~km}$ from their ALR (Fig. 3A). Two tagged weakfish (fish IDs 140 and 155) also were observed at their ALR for 4 consecutive detections but were not detected outside that region before leaving the study area. One fish (ID 137) had the lowest proportion of potential detections within an ALR (24\%; Table 1). After movement from the ALR, this individual was subsequently detected on 9 other occasions outside that region. Another small group of fish (4 of 12) were observed making excursions of varying distances (1.0-5.9 $\mathrm{km}$ ) from their ALR, followed by a return after 1-2 sampling weeks (Fig. 3B). For both groups of tagged weakfish, detections at an ALR frequently occurred during nonconsecutive sampling weeks, indicating that fish had potentially moved outside the sampling area for short (weekly) periods. Therefore, the estimate of fish that made excursions from these areas may be low.

\section{Diel patterns of movement}

Weakfish exhibited a diel periodicity of daytime residency at Deep Point (less than $0.5 \mathrm{~km}$ between detections; Fig. 4A) followed by nightly movements that began around sundown (Fig. 4B)-a finding based on the locations (155) of 9 individual weakfish that were detected by focused, intensive active tracking. For several individuals ( $n=4$; IDs $64,136,137$, and 151), their ALDR at Deep Point corresponded to seasonal ALR and original tagging location. For other fish tagged at 


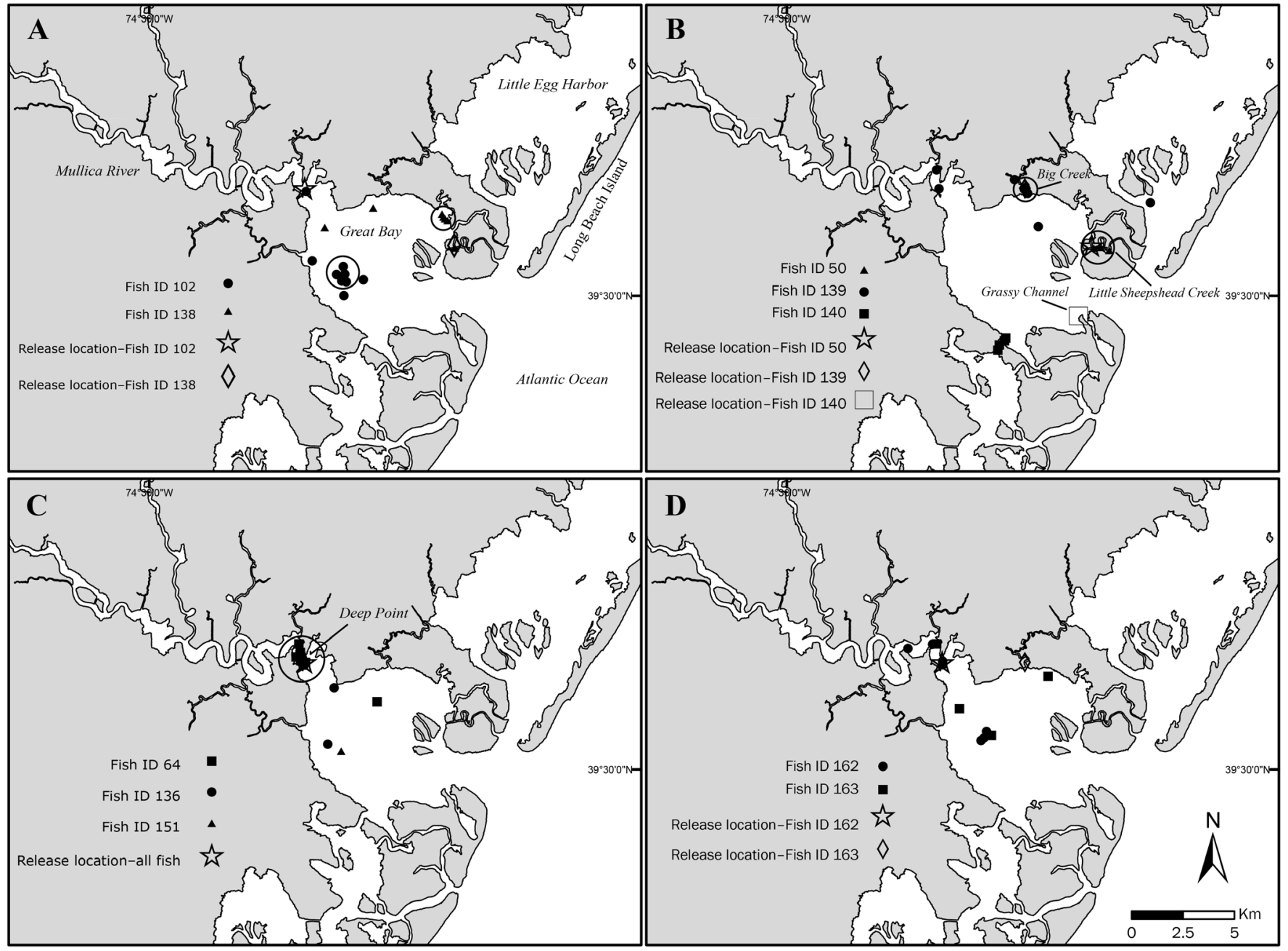

Figure 2

Release locations and representative spatial distribution patterns for weakfish (Cynoscion regalis) in the Mullica River-Great Bay estuary from June through November 2008: distribution of tagged fish that established areas of localized residency (ALR) in (A) bay, (B) subtidal creek, and (C) river habitats and (D) distribution of tagged fish that did not establish ALR but still used similar portions of the estuary. Circled points in panels A-C are detections that fit the criteria for localized residency (3 or more consecutive detections within $500 \mathrm{~m}$ of each other). For locations see Figure 1. For details for individual fish, refer to Table 1.

Deep Point ( $n=4$; IDs 62, 103, 162, and 204), where diel movement patterns were observed, no seasonal ALR was established in any estuarine location on the basis of the criteria described above. The single fish (ID 100) that was originally tagged in a different location, Big Creek (see Fig. 1) also did not fit the criteria for establishment of an ALR at any estuarine location. The duration between consecutive detections of a single individual was highly variable (12-382 $\mathrm{min}$ ), because of the variable abundance of tagged fish, the different amount of time it took for the tracking vessel to return to the location of a previous detection, and the ability to redetect tagged fish. Redetection was reduced during the nighttime period when weakfish moved from their ALDR (Table 2).

The majority of individual weakfish maintained an
ALDR during the day ( $n=8$ fish; 119 detections; mean distance from ALDR: $0.34 \mathrm{~km}$ [SE 0.04]) and moved significantly farther from that site during dusk and nighttime ( $n=7$ fish; 36 detections; mean: $1.37 \mathrm{~km}$ [SE 0.17]; Mann-Whitney $\left.U_{0.05(2), 8,7}=56, P=0.0015\right)$, although distances from ALDR were variable between individuals (Table 2; Fig. 5). Variation was driven primarily by one tagged individual (ID 103) that maintained higher-than-average distances (2.1 and $2.2 \mathrm{~km}$ ) from its ALDR during 2 time periods (0800-1000 and 1800-2000, respectively). Overall, tagged weakfish were never detected within $0.5 \mathrm{~km}$ of their ALDR after 2230 hours. Diel tracking also indicated a level of site affinity within a schooling aggregation because most fish during this portion of the study were detected within the same ALDR. 

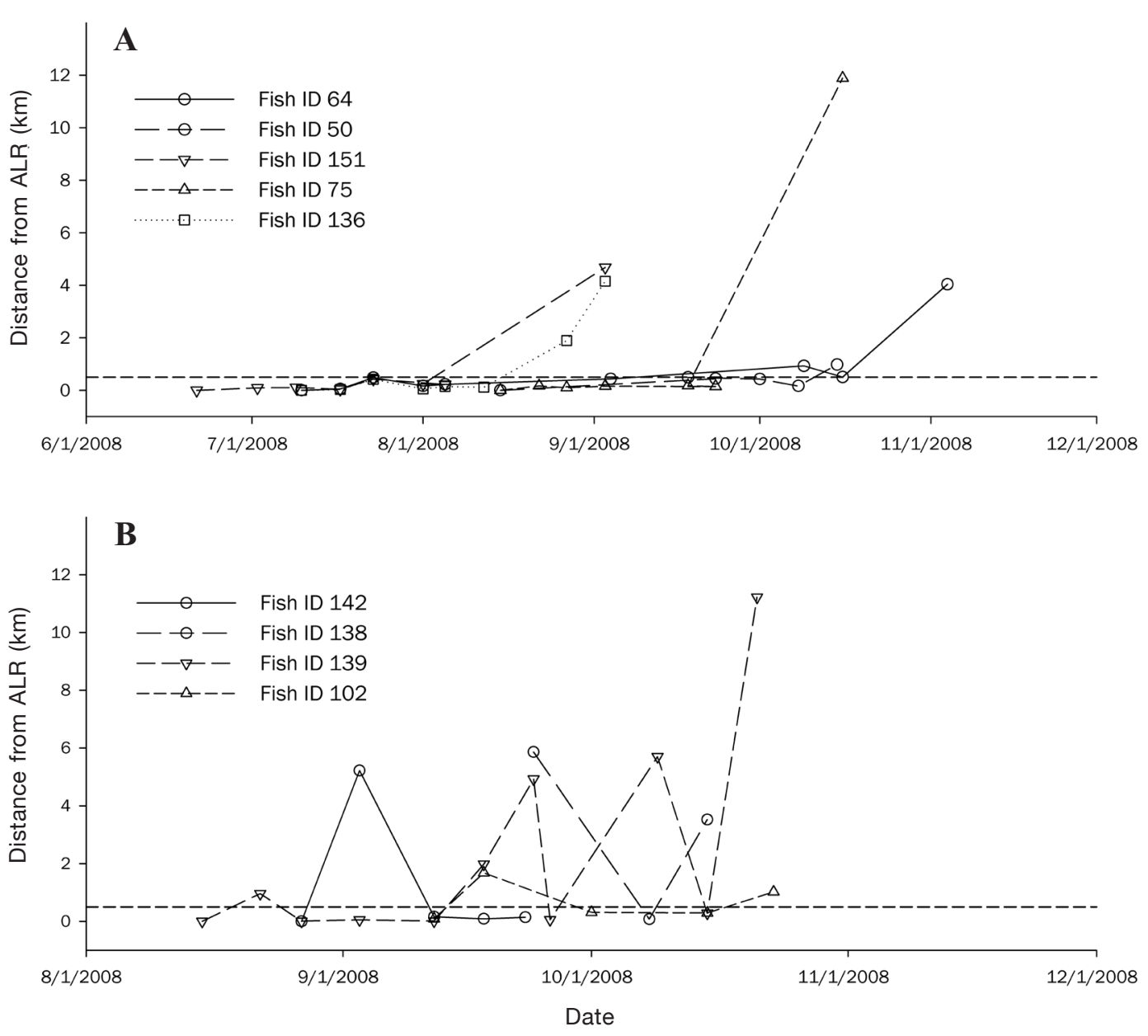

Figure 3

Variation in seasonal movement from areas of localized residency (ALR; 3 or more consecutive detections within $500 \mathrm{~m}$ of each other) from June through November 2008 for individual tagged weakfish (Cynoscion regalis) (9 of 12 fish): tagged fish with (A) restricted movements within ALR and (B) excursions from ALR. The area below the horizontal dashed line indicates distances $(<0.5 \mathrm{~km})$ within the defined ALR. For details for individual fish, refer to Table 1.

\section{Discussion}

\section{Seasonal patterns}

The data presented here indicate estuarine site affinity behavior and, in conjunction with prolonged estuarine residency times (Manderson et al., 2014; Turnure et al., in press), also indicate that many adult weakfish maintain strong spatial and temporal bonds with their seasonal estuarine residence. During this period of intra-estuarine residency, weakfish are known to reproduce (Connaughton and Taylor, 1995) and feed (Harfmart and Brandt, 1995), indicating that estuaries may provide a unique and crucial role during their life history for at least a proportion of the weakfish population. The motivations and mechanisms behind animal movements-specifically the establishment of restricted home ranges, site affinity, and homing behavior-are complex (Dingle and Holyoak, 2001; Schick et al., 2008; Lowerre-Barbieri et al., 2013; White and Brown, 2013) but are thought to occur in response to a variety of seasonal factors (Mueller and Fagan, 2008), such as patchy resource distributions (e.g., spawning habitat and prey species) and extreme water temperatures that result in physiological limitations (Pörtner, 2010).

The location and abundance of spawning aggregations and prey items are likely to influence the seasonal, intra-estuarine movements of adult weakfish. For example, the resources needed for reproductive activity could influence their site affinity patterns, as seen in other sciaenid species. In the congener spotted seat- 

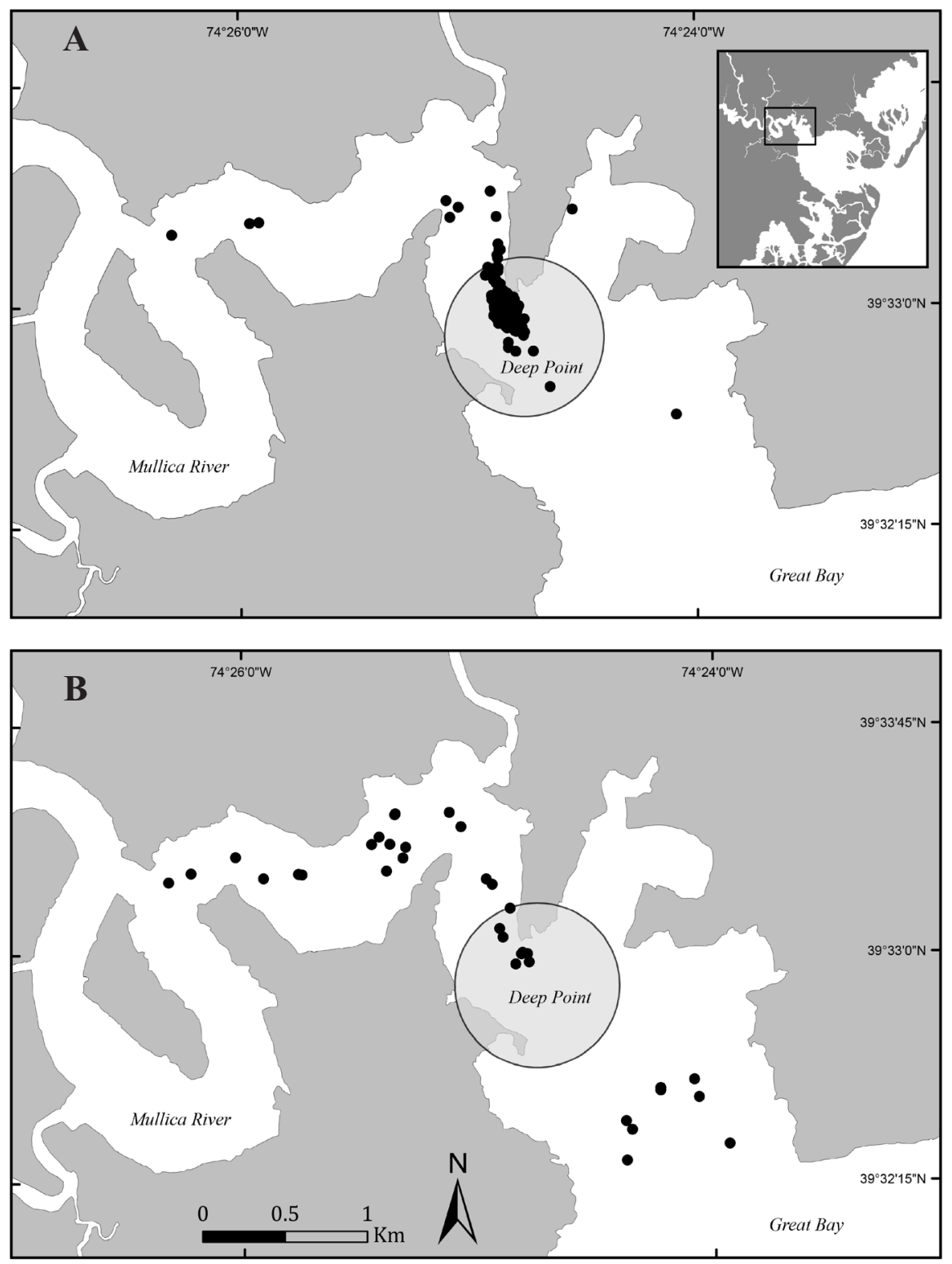

Figure 4

Cumulative active telemetric detections of tagged individual weakfish (Cynoscion regalis) at Deep Point in the lower Mullica River during (A) day (0430-19:29 hours, 119 detections of $n=8$ individuals) and (B) night (1930-0429 hours, 35 detections of $\mathrm{n}=6$ individuals) from 30 June to 31 July 312008 . The detection of an individual fish (ID 100) is not shown on this map. In each panel, a black circle (1 km in diameter) represents the area of localized daytime residency (ALDR) defined for individuals in the evaluation of diel movements as the seasonal area of localized residency (ALR) by weekly active tracking events ( 3 or more consecutive weekly detection within 500 $\mathrm{m}$ of each other). The ALDR also corresponds to the original release site for all fish except for one fish (ID 100). For locations of sampling points, see Figure 1. For details on individual tagged weakfish, refer to Table 2.

rout (Cynoscion nebulosus), strong intraseasonal site fidelity was frequently displayed (Lowerre-Barbieri et al., 2013). In red drum (Sciaenops ocellatus), space use significantly increased during the spawning period in Florida, presumably as a result of an enhanced search for spawning opportunities (Reyier et al., 2011). Sea ra- ven (Sciaena umbra) exhibited strong site attachment outside the spawning period (Alós and Cabanellas-Reboredo, 2012), similar to the pattern observed in red drum. In contrast, results of this study indicate that weakfish maintained some degree of site affinity during the spawning season, but changes in these movements 


\section{Table 2}

Detections and movements of tagged weakfish (Cynoscion regalis) ( $n=9)$ tracked on a diel basis at Deep Point (lower Mullica River) through the use of active acoustic telemetry (from 30 June 30 to 31 July 2008). For locations within study area and sampling points, see Figure 1. For tagging details on individual weakfish (except the fish (ID 100) tagged 11 June 2008 in Big Creek; $413 \mathrm{~mm}$ in total length), refer to Table 1. Standard errors of mean distances are given in parentheses.

\begin{tabular}{|c|c|c|c|c|c|c|c|}
\hline $\begin{array}{l}\text { Fish } \\
\text { ID }\end{array}$ & $\begin{array}{c}\text { First } \\
\text { detection }\end{array}$ & $\begin{array}{c}\text { Last } \\
\text { detection }\end{array}$ & $\begin{array}{l}\text { Number of } \\
\text { tracking } \\
\text { events } \\
\text { detected }\end{array}$ & $\begin{array}{c}\text { Total } \\
\text { detections } \\
\text { (day) }\end{array}$ & $\begin{array}{c}\text { Total } \\
\text { detections } \\
\text { (night) }\end{array}$ & $\begin{array}{l}\text { Daily mean } \\
\text { distance } \\
\text { from ALDR } \\
\quad(\mathrm{km})\end{array}$ & $\begin{array}{l}\text { Nightly mean } \\
\text { distance } \\
\text { from ALDR } \\
(\mathrm{km})\end{array}$ \\
\hline 62 & July 23 & July 31 & 5 & 14 & 1 & $0.20(0.02)$ & $1.24(\mathrm{n} / \mathrm{a})$ \\
\hline 64 & July 17 & July 31 & 6 & 20 & 4 & $0.21(0.09)$ & $1.10(0.21)$ \\
\hline 100 & July 22 & - & 1 & - & 1 & - & $1.36(\mathrm{n} / \mathrm{a})$ \\
\hline 103 & June 30 & July 30 & 5 & 25 & 1 & $0.50(0.12)$ & $2.27(\mathrm{n} / \mathrm{a})$ \\
\hline 136 & July 17 & July 31 & 6 & 19 & 6 & $0.30(0.03)$ & $1.49(0.28)$ \\
\hline 137 & July 10 & July 22 & 4 & 5 & 12 & $0.34(0.04)$ & $1.24(0.25)$ \\
\hline 151 & July 10 & July 31 & 8 & 24 & 11 & $0.28(0.04)$ & $0.86(0.13)$ \\
\hline 162 & June 30 & July 10 & 2 & 2 & - & $0.53(0.33)$ & - \\
\hline 204 & June 30 & - & 1 & 10 & - & $0.34(0.05)$ & - \\
\hline
\end{tabular}

before or after this period could not be ascertained. Interpretation of diel movements (see the following section) further corroborates the potential influence of reproductive behavior on weakfish movements.

Predator avoidance can also regulate the movements of fish species (Pittman and McAlpine, 2003) across varying scales but is most often discussed in the context of juveniles or subadults (Naesje et al., 2012). Although predation risk is greatest for juvenile fishes, adult movements may also be influenced by such factors. Seasonal occurrences of piscivorous predators, such as sandbar shark (Carcharhinus plumbeus; Merson and Pratt, 2005), striped bass (Morone saxatilis; Ng et al., 2007), and bottlenose dolphin (Tursiops truncatus; Toth et al., 2011) are common in the study area and may influence the movements and distribution of adult weakfish. One manifestation of a movement strategy based on predator avoidance could be periodic or long-term "stationary" behavior, as documented for Japanese croaker (Argyrosomus japonicus; Naesje et al., 2012) and the consistent, localized behavior observed with tagged weakfish detected weekly during this study for periods lasting up to 7 weeks. At the population level, variation in movement in contrast to prolonged stationary behavior of tagged weakfish, as observed in this study, could be explained by differences in an individual's boldness or propensity for habitat exploration (Fraser et al., 2001; Frost et al., 2013).

Maintenance of optimal environmental quality, especially in dynamic estuarine environments, is another potential predictor of weakfish movements (Manderson et al., 2014). Environmental quality, measured as water temperature, salinity, and dissolved oxygen, in relation to weakfish distribution was evaluated dur- ing a concurrent study, in which tagged weakfish were commonly detected within a relatively narrow range of environmental parameters near deep channel edges and emergent marsh banks and during all seasons (Turnure et al., in press). However, the consistency of detections within a narrow range of temperature, salinity, and dissolved oxygen may have been driven by a broader spatial restriction to the lower estuary rather than by directed movements to these areas within the estuary.

\section{Diel patterns}

The diel movements of tagged weakfish during this study could best be characterized as "commuting" behaviors (Dingle and Holyoak, 2001) because they took place on a short-term periodic basis and likely were initiated in a search for spawning or prey aggregations followed by a return to an ALDR. Although a high percentage of fish left the study area (Deep Point) used for examination of diel movements at night and were not detected until the following morning, several individuals were detected in other localized areas after movement away from their ALDR. This finding may indicate a shift to a new nightly ALR. Alternatively, the movement of some fish outside the study area may indicate ranging behavior for foraging. A previous investigation of nighttime use of subtidal creeks in the study area hinted at the possible use of these habitats by weakfish for nighttime feeding excursions on high tides (Rountree and Able, 1997). Initiation of movement from the ALDR at Deep Point (Fig. 1) corresponded to lower light levels and, more specifically, the nighttime crepuscular period. There was high variability in movements during the early nighttime crepuscular period 


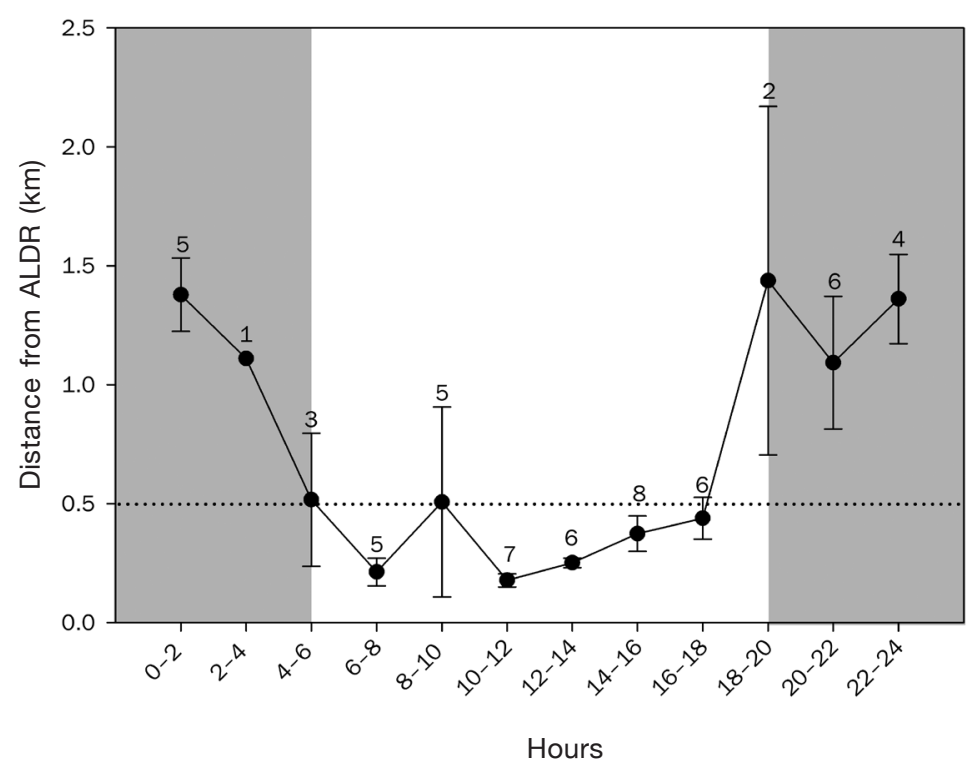

Figure 5

Diel variation in distance from area of localized daytime residency (ALDR) for individual weakfish (Cynoscion regalis) detected by using active telemetry (from 30 June to 31 July 312008 ). All weakfish $(n=9)$, except one fish (ID 100), were originally tagged at Deep Point in the lower Mullica River and distances $(\mathrm{km})$ from that site were pooled and averaged by 2 -h bins for each tagged fish. Error bars represent standard error of means for individuals and sample sizes are displayed above bars. Gray boxes indicate approximate nighttime periods (19300430 hours). The ALDR was defined for each individual in the evaluation of diel movements as the seasonal area of localized residency (ALR) by weekly active tracking events (3 or more consecutive weekly detections within $500 \mathrm{~m}$ of each other). The ALDR corresponded to the original release site (Deep Point) for all fish, except one fish (ID 100). The area below the horizontal dotted line indicates distances $(<0.5 \mathrm{~km})$ within the defined ALDR. For sampling locations, see Figure 1. For details for individual tagged weakfish, refer to Table 2.

also examined the drumming pattern of weakfish and noted that the highest level of spawning vocalizations occurred inshore during early evening (Connaughton and Taylor, 1995).

Diel movements and day-night changes in use of space are common among other sciaenid species (e.g., red drum: Dresser and Kneib, 2007; sea raven: Alós and Cabanellas-Reboredo, 2012; and Japanese croaker: Naesje et al., 2012) and in other families (e.g., white sturgeon (Acipenser transmontanus): Parsley et al., 2008; red snapper (Lutjanus campechanus): Topping and Szedlmayer, 2011) but this article provides the first description of similar behavior in weakfish. Juvenile weakfish movements in relation to diel-cycling of hypoxia events were observed during summer in a small tributary of the Delaware Bay (Tyler and Targett, 2007; Brady and Targett, 2013) and modeled (Brady et al., 2009). During the former study, juveniles exhibited a daily escape response $(\sim 1 \mathrm{~km})$ in areas where hypoxia events occurred (dissolved oxygen $<2 \mathrm{mg} / \mathrm{L}$ ), indicating that movement patterns could be more dynamic in affected systems where daily fluctuations in dissolved oxygen are common. The results from the tracking study described here represent weakfish movement patterns within a relatively undisturbed estuary where low dissolved oxygen is infrequent.

The dynamics of movements in adult weakfish appear to be related to scaling over seasonal and diel time frames, and these results represent new evidence of the affinity of adult weakfish to specific

(1800-2000), indicating that initiation of nighttime movements was dynamic among individuals (e.g., the fish with ID 103).

Nighttime is also the period when peak weakfish spawning occurs (Taylor and Villoso, 1994). Concurrent research in the study area during active tracking events confirmed nightly weakfish drumming, indicating that spawning may have occurred during the tracking period (Turnure, 2010). These results confirm observations from previous studies of weakfish movement in Delaware Bay during the sundown period that was related to spawning activity (Connaughton and Taylor, 1994). In this study, fish facing inshore (presumably in prespawning mode) were frequently caught in gill nets during the early evening hours and in the later evening (presumably after spawning), fish were caught facing offshore. Further, few fish were caught in gill nets during the early morning and early afternoon, likely the time when weakfish decreased their movements (Connaughton and Taylor, 1994). Those authors estuarine localities and of their ability to return to them from relatively large distances within an estuary across ecologically relevant time scales. Although the site fidelity of other adult fishes (e.g., summer flounder (Paralichthys dentatus): Capossela et al., 2013), including those fishes previously studied in this system (striped bass: $\mathrm{Ng}$ et al., 2007; summer flounder: Sackett et al., 2007) has been observed in small estuarine systems and site fidelity has been quantified at the regional estuarine scale for weakfish (Thorrold et al., 2001), fine-scale behaviors have not been previously quantified in adult weakfish.

In further studies of weakfish estuarine movements, one step would be to reexamine the previous model of natal homing and site fidelity in adult weakfish (Thorrold et al., 2001) at smaller spatial scales. The long-term spatial memory needed to enable a fish to return back to relatively small areas (Fukumori et al., 2010) on a yearly basis was not observed in weakfish (Turnure et al., in press), but a similar ability to relocate to an 
ALR from relatively large distances $(\sim 6 \mathrm{~km})$ within a season was evident in several individuals in this study. With the high level of individual variation present in this study and the potential effects of intrinsic (e.g., size and sex) and extrinsic (e.g., time and location of tagging and environmental quality) variables on the observed patterns of movement, these results also indicate that a prior understanding of scale (both temporal and spatial) is necessary to formulate proper research questions about weakfish movements and likely about other estuarine species.

Inherent variability in behavior of individuals, as seen in this and in previous studies (see Bolnick et al., 2003, and citations within; Kobler et al., 2009), should not be overlooked when interpreting these patterns (Mittelbach, 2014). Explicit examination of the mechanisms that surround these temporal dynamics would provide insight into weakfish movements in relation to critical aspects of their life history (e.g., reproduction) at scales beyond the individual and could be used to scale the protection of spawning habitat and to gain insight into population-level dynamics. For example, current understanding of weakfish population genetics indicates that the western Atlantic weakfish population should be managed as one coastal stock despite the existence of geographically distinct subpopulations (Cordes and Graves, 2003). Our study, described here, further confounds the notion that weakfish maintain population connectivity through highly dispersive movements during the reproductive period. Behavioral differences among and within weakfish subpopulations, especially with regard to the phenology and location of spawning, may contribute to the genetic similarity within the coastal weakfish population.

\section{Acknowledgments}

We thank technicians (T. Malatesta, S. Ordog, J. Rackovan, J. Caridad, and R. Hagan), Jacques Cousteau National Estuarine Research Reserve volunteers (R. Zaengle and K. Mancini), and National Science Foundation Research Experience Undergraduates program interns (B. Reckenbeil and A. Pogue). S. Powell contributed fish for tagging. The Estuarine Reserves Division of the NOAA Office of Ocean and Coastal Resource Management, now part of the Stewardship Division of the NOAA Office for Coastal Management, funded this study along with the Institute of Marine and Coastal Sciences of Rutgers University and the Manasquan River Marlin and Tuna Club. This article is no. 2015-2 of the Institute of Marine and Coastal Sciences.

\section{Literature cited}

\section{Able, K. W.}

2005. A re-examination of fish estuarine dependence: evidence for connectivity between estuarine and ocean habitats. Estuar. Coast. Shelf Sci. 64:5-17. Article
Able, K. W., and M. P. Fahay.

1998. The first year in the life of estuarine fishes in the Middle Atlantic Bight, 342 p. Rutgers Univ. Press, New Brunswick, NJ.

2010. Ecology of estuarine fishes: temperate waters of the western North Atlantic, 566 p. Johns Hopkins Press, Baltimore, MD.

Alós, J., and M. Cabanellas-Reboredo.

2012. Experimental acoustic telemetry experiment reveals strong site fidelity during the sexual resting period of wild brown meagre, Sciaena umbra. J. Appl. Ichthyol. 28:606-611. Article

Bolnick, D. I., R. Svanbäck, J. A. Fordyce, L. H. Yang, J. M. Davis, C. D. Hulsey, and M. L. Forister.

2003. The ecology of individuals: incidence and implications of individual specialization. Am. Nat. 161:1-28. Article

Brady, D. C., and T. E. Targett.

2013. Movement of juvenile weakfish Cynoscion regalis and spot Leiostomus xanthurus in relation to dielcycling hypoxia in an estuarine tidal tributary. Mar. Ecol. Prog. Ser. 491:199-219. Article

Brady, D. C., T. E. Targett, and D. M. Tuzzolino.

2009. Behavioral responses of juvenile weakfish $(C y$ noscion regalis) to diel-cycling hypoxia: swimming speed, angular correlation, expected displacement, and effects of hypoxia acclimation. Can. J. Fish. Aquat. Sci. 66:415-424. Article

Bright, P. W., and P. A. Morris.

1991. Ranging and nesting behaviour of the dormouse, Muscardinus avellanarius, in diverse low-growing woodland. J. Zool. 224:177-190. Article

Capossela, K. M., M. C. Fabrizio, and R. W. Brill.

2013. Migratory and within-estuary behaviors of adult Summer Flounder (Paralichthys dentatus) in a lagoon system of the southern mid-Atlantic Bight. Fish. Bull. 111:189-201. Article

Collette, B., and G. Klein-MacPhee (eds).

2002. Bigelow and Schroeder's fishes of the Gulf of Maine, 3rd ed., 882 p. Smithsonian Inst. Press, Connaughton MA.

Connaughton, M. A., and M. H. Taylor.

1994. Seasonal cycles in the sonic muscles of the weakfish, Cynoscion regalis. Fish. Bull. 92:697-703.

1995. Seasonal and daily cycles in sound production associated with spawning in the weakfish, Cynoscion regalis. Environ. Biol. Fish. 42:233-240. Article

Cordes, J. F., and J. E. Graves.

2003. Investigation of congeneric hybridization in and stock structure of weakfish (Cynoscion regalis) inferred from analyses of nuclear and mitochondrial DNA loci. Fish. Bull. 101:443-450.

Costello, C. M.

2010. Estimates of dispersal and home-range fidelity in American black bears. J. Mammal. 91:116-121. Article

Dingle, H., and M. Holyoak.

2001. The evolutionary ecology of movement. In Evolutionary ecology: concepts and case studies (C. W. Fox, D.A. Roff, D. J. Fairbairn, eds.), p. 247-261. Oxford Univ. Press, New York.

Dresser, B. K., and R. T. Kneib.

2007. Site fidelity and movement patterns of wild subadult red drum, Sciaenops ocellatus (Linnaeus), within a salt marsh-dominated estuarine landscape. Fisheries Manage. Ecol. 14:183-190. Article 
Ferraro, S. P.

1980. Daily time of spawning of 12 fishes in the Peconic Bays, New York. Fish. Bull. 78:455-464.

Fraser, D. F., J. F. Gilliam, M. J. Daley, A. N. Le, and G. T. Skalski.

2001. Explaining leptokurtic movement distributions: intrapopulation variation in boldness and exploration. Am. Nat. 158:124-135. Article

Frost, A. J., J. S. Thomson, C. Smith, H. C. Burton, B. Davis, P. C. Watts, and L. U. Sneddon.

2013. Environmental change alters personality in the rainbow trout, Oncorhynchus mykiss. Anim. Behav. 85:1199-1207. Article

Fukumori, K., N. Okuda, K. Yamaoka, and Y. Yanagisawa.

2010. Remarkable spatial memory in a migratory cardinalfish. Anim. Cogn. 13:385-389. Article

Good, R. E., and N. F. Good.

1984. The Pinelands National Reserve: an ecosystem approach to management. Bioscience 34:169-173. Article

Harfmart, K. J., and S. B. Brandt.

1995. Predatory demand and impact of striped bass, bluefish, and weakfish in the Chesapeake Bay: applications of bioenergetics models. Can. J. Fish. Aquat. Sci. 52:1667-1687. Article

Hoppes, W. G.

1987. Pre-and post-foraging movements of frugivorous birds in an eastern deciduous forest woodland, USA. Oikos 49:281-290. Article

Humston, R., J. S. Ault, M. F. Larkin, and J. Luo.

2005. Movements and site fidelity of the bonefish Albula vulpes in the northern Florida Keys determined by acoustic telemetry. Mar. Ecol. Prog. Ser. 291:237-248. Article

Kennish, M. J.

2001. Physical description of the Barnegat Bay-Little Egg Harbor estuarine system. J. Coast. Res. Spec. Iss. 32:167-177. Article

2004. Jacques Cousteau National Estuarine Research Reserve. In Estuarine research monitoring and resource protection (M. J. Kennish, ed.) p. 59-115. CRC Press, Boca Raton, FL.

Kennish, M. J., and S. O'Donnell

2002. Water quality monitoring in the Jacques Cousteau National Estuarine Research Reserve System. Bull. NJ Acad. Sci. 47:1-14.

Kobler, A., T. Klefoth, T. Mehner and R. Arlinghaus.

2009. Coexistence of behavioural types in an aquatic top predator: a response to resource limitation? Oecologia 161:837-847. Article

Levin, S. A.

1992. The problem of pattern and scale in ecology: the Robert H. MacArthur award lecture. Ecology 73:1943-1967. Article

Lowerre-Barbieri, S. K., M. E. Chittenden Jr., and L. R.

Barbieri.

1996. Variable spawning activity and annual fecundity of weakfish in Chesapeake Bay. Trans. Am. Fish. Soc. 125:532-545. Article

Lowerre-Barbieri, S. K., S. Walters, J. Bickford, W. Cooper, and R. Muller.

2013. Site fidelity and reproductive timing at a spotted seatrout spawning aggregation site: individual versus population scale behavior. Mar. Ecol. Prog. Ser. 481:181-197. Article
Luczkovich, J. J., M. W. Sprague, S. E. Johnson, and R. C. Pullinger.

1999. Delimiting spawning areas of weakfish Cynoscion regalis (Family Sciaenidae) in Pamlico Sound, North Carolina using passive hydroacoustic surveys. Bioacoustics 10:143-160.

Manderson, J. P., L. L. Stehlik, J. Pessutti, J. Rosendale, and B. Phelan.

2014. Residence time and habitat duration for predators in a small mid-Atlantic estuary. Fish. Bull. 112: 144-158. Article

March, D., M. Palmer, J. Alós, A. Grau, and F. Cardona.

2010. Short-term residence, home range size and diel patterns of the painted comber Serranus scriba in a temperate marine reserve. Mar. Ecol. Prog. Ser. 400:195-206. Article

McGrath, P., and H. A. Austin

2009. Site fidelity, home range, and tidal movements of white perch during the summer in two small tributaries of the York River, Virginia. Trans. Am. Fish. Soc. 138:966-974. Article

Merson, R. R., and H. L. Pratt Jr.

2005. Sandbar shark nurseries in New Jersey and New York: evidence of northern pupping grounds along the United State east coast. Am. Fish. Soc. Symp., vol. 20.

Mitamura, H., K. Uchida, Y. Miyamoto, N. Arai, T. Kakihara,

T. Yokota, and T. Yasuda.

2009. Preliminary study on homing, site fidelity, and diel movement of black rockfish Sebastes inermis measured by acoustic telemetry. Fish. Sci. 75:1133-1140. Article

Mittelbach, G. G., N. G Ballew, and M. K. Kjelvik.

2014. Fish behavioral types and their ecological consequences. Can. J. Fish. Aquat. Sci. 71:927-944. Article

Mueller, T., and W. F. Fagan.

2008. Search and navigation in dynamic environments from individual behaviors to population distributions. Oikos 117:654-664. Article

Næsje, T. F., P. D. Cowley, O. H. Diserud, A. R. Childs, S. E. Kerwath, and E. B. Thorstad.

2012. Riding the tide: estuarine movements of a sciaenid fish, Argyrosomus japonicus. Mar. Ecol. Prog. Ser 460:221-232. Article

Nesbit, R. A.

1954. Weakfish migration in relation to conservation. U.S. Fish Wildl. Serv., Spec. Sci. Rep. Fish. 115, $81 \mathrm{p}$.

Ng, C. L., K. W. Able, and T. M. Grothues.

2007. Habitat use, site fidelity, and movement of adult striped bass in a southern New Jersey estuary based on mobile acoustic telemetry. Trans. Am. Fish. Soc. 136:1344-1355. Article

Nye, J. A., T. E. Targett, T. E. Helser.

2008. Reproductive characteristics of weakfish in Delaware Bay: implications for management. N. Am. J. Fish. Manage. 28:1-11. Article

Parsley, M. J., N. D. Popoff, C. D. Wright, and B. K.van der Leeuw.

2008. Seasonal and diel movements of white sturgeon in the lower Columbia River. Trans. Am. Fish. Soc. 137:1007-1017. Article

Pittman, S. J., and C. A. McAlpine.

2003. Movements of marine fish and decapod crustaceans: process, theory, and application. Adv. Mar. Bio. 44:205-294. Article 
Pörtner, H. O.

2010. Oxygen- and capacity-limitation of thermal tolerance: a matrix for integrating climate-related stressor effects in marine ecosystems. J. Exp. Biol. 213:881-893. Article

Reyier, E. A., R. H. Lowers, D. M. Scheidt, and D. H. Adams. 2011. Movement patterns of adult red drum, Sciaenops ocellatus, in shallow Florida lagoons as inferred through autonomous acoustic telemetry. Environ. Biol. Fish. 90:343-360. Article

Rogers, K. B., and G. C. White

2007. Analysis of movement and habitat use from telemetry data. In Analysis and interpretation of freshwater fisheries data (C. S. Guy, M. L. Brown, eds.), p. 625-676. Am. Fish. Soc., Bethesda, MD.

Rountree, R. A., and K. W. Able.

1997. Nocturnal fish use of New Jersey marsh creek and adjacent bay shoal habitats. Estuar. Coast. Shelf Sci. 44:703-711. Article

Sackett, D. K., K. W. Able, and T. M. Grothues.

2007. Dynamics of summer flounder, Paralichthys dentatus, seasonal migrations based on ultrasonic telemetry. Estuar. Coast. Shelf Sci. 74:119-130. Article

Schick, R. S., S. R. Loarie, F. Colchero, B. D. Best, A. Boustany,

D. A. Conde, P. N. Halpin, L. N. Joppa, C. M. McClellan, and

J. S. Clark.

2008. Understanding movement and movement processes: current and emerging directions. Ecol. Lett. 11:1338-1350. Article

Seaman, D. E., J. J. Millspaugh, B. J. Kernohan, G. C. Brundige, K. J. Raedeke, and R. A. Gitzen.

1999. Effects of sample size on kernel home range estimates. J Wildlife Manage 63:739-747. Article

Shepherd, G. R., and C. B. Grimes.

1984. Reproduction of weakfish, Cynoscion regalis, in the New York Bight and evidence for geographically specific life history characteristics. Fish. Bull. 82:501-511.
Taylor, M. H., and E. P. Villoso.

1994. Daily ovarian and spawning cycles in weakfish. Trans. Am. Fish. Soc. 123:9-14. Article

Thorrold, S. R., C. Latkoczy, P. K. Swart, and C. M. Jones.

2001. Natal homing in a marine fish metapopulation. Science 291:297-299. Article

Topping, D. T., and S. T. Szedlmayer.

2011. Site fidelity, residence time and movements of red snapper Lutjanus campechanus estimated with long-term acoustic monitoring. Mar. Ecol. Prog. Ser. 437:183-200. Article

Toth, J. L., A. A. Hohn, K. W. Able, and A. M. Gorgone.

2011. Patterns of seasonal occurrence, distribution, and site fidelity of coastal bottlenose dolphins (Tursiops truncatus) in southern New Jersey, USA. Mar. Mammal Sci. 27:94-110. Article

Turnure, J. T.

2010. Estuarine habitat ecology of adult weakfish ( $C y$ noscion regalis): a multi-scale approach. M.S. thesis, 139 p. Rutgers Univ., New Brunswick, N.J. [Available from http://search.proquest.com/docview/847340803.]

Turnure, J. T., T. M. Grothues, and K. W. Able.

In press. Seasonal residency of adult weakfish $(C y$ noscion regalis) in a small temperate estuary based on acoustic telemetry: a local perspective of a coast wide phenomenon. Environ. Biol. Fish. Article

Tyler, R. M., and T. E. Targett

2007. Juvenile weakfish Cynoscion regalis distribution in relation to diel-cycling dissolved oxygen in an estuarine tributary. Mar. Ecol. Prog. Ser. 333:257-26. Article

White, G. E., and C. Brown.

2013. Site fidelity and homing behavior in intertidal fishes. Mar. Biol. 160:1365-1372. Article

Woodland, R. J., D. H. Secor, M. C. Fabrizio, and M. J. Wilberg.

2012. Comparing the nursery role of inner continental shelf and estuarine habitats for temperate marine fishes. Estuar. Coast. Shelf S. 99:61-73. Article 